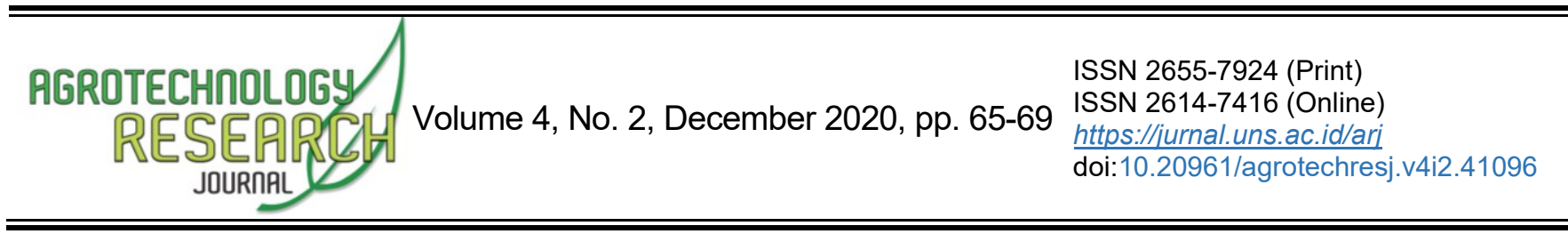

\title{
Rekayasa Dosis Nutrisi Melalui Drip Irrigation System terhadap Produksi Tomat Cherry (Solanum pimpinellifolium) Lokal Subang
}

\author{
Enceng Sobari ${ }^{1 *}$ \\ ${ }^{1}$ Politeknik Negeri Subang, Subang, Jawa Barat, Indonesia
}

Received 10 April 2020; Accepted 15 September 2020; Published 1 December 2020

\begin{abstract}
Tomatoes are easily damaged horticultural products, so that further handlings are needed in food production in the industry today. In order to keep availability, there is an increase in tomato fruit volume as raw material. Among them with increasing types and varieties of tomatoes that need to be continuously developed to supply the industry's needs. The research aimed to increase local tomato cherry production in Subang through an engineering strategy of nutrient feeding with a drip irrigation system. Research conducted from April to December 2019 at Cigadung Subang, West Java. The research was conducted using the Completely Randomized Design (CRD) one factor and the Duncan's test at 7 nutritional dose treatment consists of $\mathrm{P} 1=$ dose $5 \mathrm{ml}, \mathrm{P} 2=$ dose $7 \mathrm{ml}, \mathrm{P} 3=$ dose $10 \mathrm{ml}, \mathrm{P} 4=$ dose $15 \mathrm{ml}$, $\mathrm{P} 5=$ dose $20 \mathrm{ml}, \mathrm{P} 6=$ dose $25 \mathrm{ml}, \mathrm{P} 7=$ Control with 5 repetition. The results concluded that two applications of nutritional doses at 7 and $10 \mathrm{ml}$ could give different responses that increase the diameter and thickness of the fruits.
\end{abstract}

Keywords: Crop development; Crop result characters; Improved results; Hydroponic; Nutrient feeding

Cite This As (CSE Style): Sobari E. 2020. Rekayasa Dosis Nutrisi Melalui Drip Irrigation System terhadap Produksi Tomat Cherry (Solanum pimpinellifolium) Lokal Subang. Agrotech Res J. 4(2): 65-69. https://doi.org/10.20961/agrotechresj.v4i2.41096

\section{PENDAHULUAN}

Tomat merupakan produk hortikultura yang memiliki sifat mudah rusak terhadap benturan atau semacamnya. Selain itu tomat memiliki umur daya simpan yang cukup singkat karena mengandung kadar air yang tinggi di dalam daging buahnya. Ada beberapa hal yang dapat mempengaruhi kualitas, kuantitas, dan mempengaruhi produksi tomat, antara lain dalam teknik budidaya, seperti pemupukan dan pemberian air bagi tanaman tomat (Sahera et al., 2012). Tanaman tomat sangat peka terhadap ketersediaan air, terutama dalam budidaya tomat di wilayah dataran rendah atau di daerah-daerah kekurangan air karena curah hujan yang sedikit, sehingga sangat diperlukan teknik pemberian air efektif. Tanaman dapat tumbuh dan produktivitasnya akan optimal bila ketersediaan air untuk tanaman diberikan dalam jumlah dan waktu yang tepat, sehingga diperlukan sistem irigasi tetes untuk hemat air, dan memudahkan dalam bercocok tanam (Maulana dan Idrus 2010). Kekurangan air dapat mengakibatkan terhambatnya pertumbuhan tanaman. Pemberian air dan dosis nutrisi

${ }^{*}$ Corresponding Author:

E-Mail: ncesobari@gmail.com pada tanaman tomat akan mempengaruhi proses fotosintesis (Nio Song 2012).

Sistem irigasi tetes merupakan metode pengairan yang memanfaatkan tabung dan drippers sebagai penghantar air dan nutrisi sebagai unsur hara yang dibutuhkan tanaman. Prinsip kerja metode ini menggunakan tekanan rendah untuk mendorong larutan nutrisi bersama air langsung menuju akar tanaman. Metode ini memiliki kegunaan yang jauh lebih efisiensi dan efektif dalam penggunaan air sampai 95\% dibandingkan dengan sistem penyiraman secara manual (Sobari 2015). Faktor yang mempengaruhi keberhasilan pengembangan dan produksi tanaman yaitu pemupukan yang merupakan suatu kegiatan menambah unsur hara pada tanaman. Pemupukan tersebut harus memperhatikan, diantaranya melalui pemupukan yang harus tepat jenis, tepat waktu, tepat tempat, tepat cara, dan tepat dosis. Ketersediaan unsur hara dalam tanah sangat terbatas sehingga diperlukan asupan nutrisi tambahan agar membantu proses pertumbuhan dan perkembangan tanaman tomat (Venkadeswaran et al. 2018).

Memproduksi sayuran dengan cara hidroponik pada umumnya menggunakan unsur hara berupa larutan nutrisi standar seperti AB mix (Nugraha dan Susila, 2015). Larutan tersebut memiliki kandungan hara yang lengkap dan dibutuhkan tanaman yang terdiri dari 
garam-garam makro dan mikro yang diformulasi dalam larutan stok $A$ dan $B$ ditambah dengan air. Larutan nutrisi stok $A$ terdiri atas unsur sedangkan larutan pada stok $B$ terdiri dari:

Tabel 1. Kandungan unsur hara dalam $A B$ mix

\begin{tabular}{ll}
\hline Unsur Hara & $\begin{array}{l}\text { Kandungan } \\
(\mathbf{g} / \mathbf{5 0 0 0} \text { I) }\end{array}$ \\
\hline Stok A : & \\
$\mathrm{Ca}\left(\mathrm{NO}_{3}\right)_{2}$ & 4850 \\
$\mathrm{Fe} \mathrm{EDTA} 12 \%$ & 86 \\
Stok B : & \\
$\mathrm{KNO}_{3}$, & 4420 \\
$\mathrm{KH}_{2} \mathrm{PO}_{4}$, & 1360 \\
$\mathrm{MgSO}_{4}$, & 1230 \\
$\mathrm{~K}_{2} \mathrm{SO}_{4}$, & 298 \\
$\mathrm{MnSO}_{4}$, & 4,2 \\
$\mathrm{ZnSO}$ & \\
$\mathrm{Borax}_{4}\left(\mathrm{NaBO}_{4} \mathrm{O}_{7}, 10 \mathrm{H}_{2} \mathrm{O}\right)$, & 5,4 \\
$\mathrm{CuSO}_{4}$, & 14,3 \\
$\mathrm{Na}_{2} \mathrm{MoO}_{4} 2 \mathrm{H}_{2} \mathrm{O}$ & 0,94 \\
\hline
\end{tabular}

Sumber: Muhadiansyah, Setyono, dan Adimihardja (2016)

Unsur hara makro dan mikro pada larutan $A B$ mix sangat berpengaruh pada pertumbuhan tanaman diantaranya sayuran daun seperti selada merah (Ainina dan Aini 2018). Persoalan budidaya tomat cherry dataran rendah terletak pada kurangnya kesuburan tanah, sumber air, dan kelembapannya, sehingga diperlukan asupan nutrisi sebagai penunjang pertumbuhan tanaman tomat cherry (Manalu et al. 2019). Sama halnya pada penelitian Romalasari dan Sobari (2019) menyatakan bahwa unsur utama pada nutrisi $A B$ mix diperlukan dan dibutuhkan tanaman untuk tumbuh seperti nitrogen $(N)$, fosfor $(P)$, dan kalium $(K)$.

Tomat cherry atau Solanum pimpinellifolium (L.) Mill., merupakan tanaman semak yang sudah lama dijumpai di daerah pesisir Selatan dan Tengah wilayah Peru dan tumbuh dipinggir jalan. Saat ini keberadaannya sudah sangat langka, namun di bagian Peru Utara populasi tanaman ini masih tumbuh banyak (Caicedo dan Schaal 2004). Tanaman ini belum banyak dimanfaatkan keberadaannya, bahkan sering dianggap tanaman liar (Sobari dan Piarna 2019). Saat ini perkembangan industri makanan banyak memanfaatkan buah tomat sebagai salah satu bahan baku industri seperti saus dan produk lainnya. Tomat cherry memiliki kandungan vitamin $C$ tinggi, rasa yang lebih manis dan segar dan memiliki nilai ekonomi yang jauh lebih baik dibandingkan dengan tomat biasa. Ketersediaannya masih rendah di pasar lokal, bahkan belum banyak yang membudidayakan karena varietas tomat cherry masih terbatas (Sobari et al., 2019).

Adapun tujuan penelitian ini adalah untuk mengetahui aplikasi dosis nutrisi terbaik pada tomat cherry lokal Subang sebagai salah satu rekomendasi dalam meningkatkan produksi tomat cherry.

\section{BAHAN DAN METODE}

Penelitian dilaksanakan pada April-Desember 2019 di Kabupaten Subang. Bahan yang digunakan berupa koleksi aksesi tomat cherry lokal Subang dengan sistem pertumbuhan satu cabang per tanaman. Frekuensi dan volume penyiraman dilakukan sebanyak 2 kali pada pagi dan sore hari sebanyak $300 \mathrm{~mL} /$ tanaman berdasarkan hasil perhitungan dengan menggunakan Cropwat dari data FAO adalah $25 \mathrm{~mm} \cdot \mathrm{dec}^{-1}$ (Smith M. 1992). Sehingga jika dihitung berdasarkan jumlah populasi dan luas lahan yang dibutuhkan sebagai berikut:

$$
\begin{array}{ll}
\text { Diketahui: } & \\
\text { Kebutuhan air tanaman } & =25 \mathrm{~mm} \cdot \mathrm{dec}^{-1} \\
& =25 \mathrm{~L} \cdot \mathrm{m}^{-1} \cdot \mathrm{dec}^{-1} \\
& =4,5 \mathrm{~m} 2 \\
\text { Luas lahan } & =35 \text { tanaman }
\end{array}
$$

Maka:

$$
\begin{aligned}
25 \mathrm{~mm} \cdot \mathrm{dec}^{-1} & =25 \mathrm{~L} \cdot \mathrm{m}^{-1} \cdot \mathrm{dec}^{-1} \\
& =\frac{\text { kebutuhan air tanaman } \times \text { luas lahan }}{\text { jumlah populasi tanaman }} \\
& =\left(11,25 \mathrm{~L} 4,5 \cdot \mathrm{m}^{-1}\right) / 35 \text { tanaman } \\
& =0,3 \mathrm{~L} / \text { tanaman }=300 \mathrm{~mL} / \text { tanaman }
\end{aligned}
$$

Media tanam menggunakan kombinasi sekam padi dan tanah dengan perbandingan $2: 1$, yaitu satu ember ukuran volume $5 \mathrm{~kg}$ berbanding 2 ember sekam volume $5 \mathrm{~kg}$. Nutrisi menggunakan pupuk $A B$ mix dengan $E C$ berkisar 3954-9705 $\mu \mathrm{s} / \mathrm{cm}$ yang dibuat sebanyak 7 formulasi terdiri dari; $\mathrm{P} 1=$ dosis $5 \mathrm{ml}, \mathrm{P} 2=$ dosis $7 \mathrm{ml}$, $\mathrm{P} 3=$ dosis $10 \mathrm{ml}, \mathrm{P} 4=$ dosis $15 \mathrm{ml}, \mathrm{P} 5=$ dosis $20 \mathrm{ml}, \mathrm{P} 6$ $=$ dosis $25 \mathrm{ml}, \mathrm{P} 7=$ Kontrol. Dosis nutrisi dicampur dengan $1000 \mathrm{ml}$ air bersih dan $\mathrm{pH}$ larutan diukur menggunakan $\mathrm{pH}$ tester digital. Rancangan percobaan menggunakan Rancangan Acak Lengkap (RAL) dengan lima ulangan.

Uji lanjut menggunakan Uji Jarak Berganda Duncan (UJBD) taraf 5\%. Parameter hasil yaitu diameter buah, tebal buah, bobot buah per tangkai, bobot basah tanaman, bobot kering tanaman, bobot basah akar, bobot kering akar).

\section{HASIL DAN PEMBAHASAN}

Diameter buah. Memiliki rata-rata berkisar antara $10,89 \mathrm{~mm}$ sampai $14,79 \mathrm{~mm}$. Berdasarkan hasil analisis menunjukkan berbeda nyata terhadap perlakuan P1 (5 $\mathrm{ml}$ ) dengan rata-rata $10,89 \mathrm{~mm}$, perlakukan $\mathrm{P} 2(7 \mathrm{ml})$ rata-rata $14,79 \mathrm{~mm}, \mathrm{P} 3(10 \mathrm{ml})$ rata-rata $13,82 \mathrm{~mm}$. P4 $(15 \mathrm{ml})$ rata-rata $14,60 \mathrm{~mm}$ dan $\mathrm{P} 5(20 \mathrm{ml})$ rata-rata $14.18 \mathrm{~mm}$ berdasarkan Tabel 2 .

Tebal buah. Memperlihatkan kisaran rata-rata nilai $10,27 \mathrm{~mm}$ sampai $13,15 \mathrm{~mm}$. Secara statistik menunjukkan bahwa terjadi perbedaan nyata pada perlakuan P1 (5 ml) dengan rata-rata 10,27 mm dan P2 (7 ml) dengan rata-rata $14,34 \mathrm{~mm}$ sebagaimana pada Tabel 2. Sedangkan perlakukan $P 3(10 \mathrm{ml})$ rata-rata $13,13 \mathrm{~mm}$, yang memperlihatkan berbeda nyata pada Tabel 2. 
Berdasarkan hasil data pada diameter buah dan tebal buah (Tabel 2) dapat diasumsikan bahwa penyerapan unsur hara oleh tanaman melalui metode irigasi tetes cukup efektif pada kedua karakter hasil yang diamati tersebut, sehingga mampu meningkatkan secara langsung diameter dan tebal buah. Pengaruh lain selama percobaan diantaranya yaitu suhu selama penelitian berkisar $30,3{ }^{\circ} \mathrm{C}$ sehingga mempengaruhi terhadap ketersediaan air yang diserap tanaman dan pada saat proses fotosintesis. Menurut Hapsari et al. (2017) suhu ideal untuk pertumbuhan tomat adalah berkisar $18-25^{\circ} \mathrm{C}$. Faktor lingkungan dapat menghambat metabolisme fisiologi tanaman tomat cherry dan pertumbuhan tanaman dari fase vegetatif ke fase generatif (Oliveira et al. 2018). Faktor lingkungan tersebut bisa internal seperti genetik maupun eksternal. eksternal meliputi suhu, cahaya kelembaban, dan pemupukan (Magdalena et al. 2014). Suhu sebagai faktor lingkungan juga mampu mempengaruhi produksi tanaman secara fisiologi dimana suhu dapat mempengaruhi pertumbuhan tanaman, proses fotosintesis, pembentukan stomata pada daun, mekanisme respirasi, proses kelarutan zat, laju kecepatan reaksi, kestabilan suatu enzim dan kesetimbangan berbagai sistem dan persenyawaan lainnya (Wijayanti dan Susila 2013).

Bobot buah per tangkai. Data menunjukkan bahwa karakter bobot buah per tangkai berbeda tidak nyata pada setiap perlakuan yang diberikan (Tabel 2). Secara nilai rata-rata maka perlakuan $\mathrm{P} 1$ dan $\mathrm{P} 7$ yang memiliki bobot buah per tangkai paling rendah dari semua perlakuan yang diamati. Ketidakpengaruhan perlakuan dosis pada bobot buah terjadi akibat faktor lingkungan terhadap proses fisiologi tanaman, yang menyebabkan kehilangan bobot tertinggi terjadi pada buah tomat yang mengalami fase mature-green dimana tingkat dehidrasi tertinggi terjadi dalam jaringan yang muda. Hal ini yang berakibat mempengaruhi kehilangan bobot dari buat tersebut (Zebua et al., 2019).

Bobot basah dan kering tanaman. Persentase pembentukan buah tomat dipengaruhi oleh lingkungan tumbuh tanaman salah satunya adalah faktor terbentuknya buah yaitu jumlah bunga. Pengamatan karakter bobot basah tanaman memperlihatkan data kisaran antara 42,8 g - 78,8 g. Secara keseluruhan perlakuan yang diamati tidak berbeda nyata dan P5 (20 $\mathrm{ml}$ ) merupakan nilai rata-rata tertinggi dari perlakuan yang diamati. Sedangkan bobot kering tanaman, menunjukkan nilai berkisar antara 12,00 g - 20,20 g. Bobot kering tanaman tertinggi terdapat pada P5 (20 ml) yaitu $20,20 \mathrm{~g}$ dan yang terendah terdapat pada P1 (5 ml) yaitu $12,00 \mathrm{~g}$.

Tanaman dengan perlakukan irigasi tetes memiliki tinggi tanaman yang lebih tinggi. Hal ini diakibatkan oleh proses perkembangan sel-sel pada saat tumbuh. Aktivitas pertumbuhan sel disebabkan xilem yang mengakibatkan kambium terdorong keluar yang selanjutnya membentuk sel-sel baru sehingga terjadi peningkatan tinggi tanaman (Wasonowati 2016). Karena tanaman yang lebih tinggi memberikan aspek organ vegetatif yang lebih baik dan menghasilkan fotosintat dari hasil fotosintesis lebih optimal dibandingkan dengan tanaman yang pendek.

Bobot basah dan kering akar. Dapat dilihat pada data Tabel 2 menunjukkan hal yang sama yaitu tidak terdapat perbedaan yang nyata pada setiap perlakuan, nilai rata-rata sebaran yang diperoleh rata-rata berkisar 3,6 g- 5,4 g. Sedangkan berdasarkan Tabel 2 bobot kering akar memperlihatkan nilai rata-rata berkisar 0,97 $\mathrm{g}-1,41 \mathrm{~g}$, namun secara keseluruhan karakter bobot kering akar tidak menunjukkan perbedaan yang nyata.

Selain itu unsur hara juga dapat menjadi pengaruh pada perkembangan parameter hasil tanaman tomat cherry, seperti nitrogen yang merupakan salah satu unsur hara makro, menjadi komponen penyusun asam nukleat dan asam amino. Nitrogen juga berperan sangat penting sebagai penyusun klorofil, mekanisme terpenting dalam proses fotosintesis tanaman (Ramdani et al., 2018).

Banyaknya jumlah klorofil pada daun dalam proses fotosintesis pada tanaman tomat cherry tidak berjalan secara maksimal. Akibat kekurangan kandungan nitrogen (N) mengakibatkan menurunnya aktivitas metabolisme tanaman yang dapat menimbulkan klorosis (Murtic et al. 2018). Begitu pula fosfor (P) dan kalium (K) berperan dalam pertumbuhan vegetatif maupun generatif dalam membantu perkembangan batang (Naibaho et al., 2012).

Tomat membutuhkan fosfor $(P)$ yang berguna berperan sebagai penunjang pertumbuhan serta produksi. Fosfor mempunyai peranan penting bagi tanaman tomat yang berfungsi dalam mempercepat pertumbuhan akar, mempercepat serta memperkuat pertumbuhan tanaman muda dan mempercepat pembungaan (Baker dan Pilbeam 2015).

Hal ini menunjukkan bahwa perbedaan dosis nutrisi pada tanaman dengan pemberian volume yang sama setiap tanaman dengan sistem irigasi tetes tidak menunjukkan perubahan yang signifikan pada setiap perlakuan. Selain itu pada penelitian ini menggunakan sistem budidaya satu cabang per tanaman, faktor ini yang menyebabkan karakter-karakter yang diamati tidak menunjukkan perbedaan yang nyata.

Sistem budidaya menggunakan satu cabang utama menghasilkan daun yang lebih sedikit dibandingkan penggunaan dua cabang sehingga proses fotosintesis dapat meningkatkan bobot buah (Nasrulloh et al. 2016). Namun berdasarkan penelitian (Hapsari et al. 2017) pengurangan jumlah cabang tetap memberikan pengaruh yang sama terhadap pertumbuhan tanaman. Faktor ketidaksignifikan parameter hasil bobot dikarenakan semakin banyak jumlah buah yang dipelihara. Sehingga ukuran buah akan semakin kecil yang menyebabkan bobot buah menurun. Penurunan ukuran buah tomat cherry yang semakin banyak disebabkan hasil fotosintat tidak cukup untuk memenuhi kapasitas untuk meningkatkan ukuran buah (Hapsari et al. 2017). 
Tabel 2. Pengaruh berbagai jenis dosis nutrisi terhadap pertumbuhan dan hasil tomat cherry

\begin{tabular}{lccccccc}
\hline \multirow{2}{*}{$\begin{array}{l}\text { Jenis dan } \\
\text { dosis nutrisi }\end{array}$} & $\begin{array}{c}\text { Diameter } \\
\text { buah }\end{array}$ & $\begin{array}{c}\text { Tebal } \\
\text { buah }\end{array}$ & $\begin{array}{c}\text { Bobot buah } \\
\text { per tangkai }\end{array}$ & $\begin{array}{c}\text { Bobot basah } \\
\text { tanaman }\end{array}$ & $\begin{array}{c}\text { Bobot kering } \\
\text { tanaman }\end{array}$ & $\begin{array}{c}\text { Bobot } \\
\text { basah akar }\end{array}$ & $\begin{array}{c}\text { Bobot } \\
\text { kering akar }\end{array}$ \\
\cline { 2 - 8 } & $(\mathrm{mm})$ & $(\mathrm{mm})$ & $(\mathrm{g})$ & $(\mathrm{g})$ & $(\mathrm{g})$ & $(\mathrm{g})$ & $(\mathrm{g})$ \\
\hline P1 $(5 \mathrm{ml})$ & $10,89 \mathrm{a}$ & $10,27 \mathrm{a}$ & $3,67 \mathrm{a}$ & $42,8 \mathrm{a}$ & $12,00 \mathrm{a}$ & $3,8 \mathrm{a}$ & $1,40 \mathrm{a}$ \\
P2 $(7 \mathrm{ml})$ & $14,79 \mathrm{~b}$ & $14,34 \mathrm{~b}$ & $5,30 \mathrm{a}$ & $62,6 \mathrm{a}$ & $14,80 \mathrm{a}$ & $3,6 \mathrm{a}$ & $0,97 \mathrm{a}$ \\
P3 $(10 \mathrm{ml})$ & $13,82 \mathrm{ab}$ & $13,13 \mathrm{ab}$ & $6,47 \mathrm{a}$ & $68,8 \mathrm{a}$ & $16,20 \mathrm{a}$ & $4,2 \mathrm{a}$ & $1,19 \mathrm{a}$ \\
P4 $(15 \mathrm{ml})$ & $14,60 \mathrm{~b}$ & $13,15 \mathrm{ab}$ & $5,59 \mathrm{a}$ & $56,4 \mathrm{a}$ & $13,40 \mathrm{a}$ & $4,2 \mathrm{a}$ & $1,32 \mathrm{a}$ \\
P5 $(20 \mathrm{ml})$ & $14,18 \mathrm{ab}$ & $12,98 \mathrm{ab}$ & $6,83 \mathrm{a}$ & $78,8 \mathrm{a}$ & $20,20 \mathrm{a}$ & $5,4 \mathrm{a}$ & $1,41 \mathrm{a}$ \\
P6 $(25 \mathrm{ml})$ & $13,15 \mathrm{ab}$ & $12,59 \mathrm{ab}$ & $6,53 \mathrm{a}$ & $73,8 \mathrm{a}$ & $17,20 \mathrm{a}$ & $4,4 \mathrm{a}$ & $1,40 \mathrm{a}$ \\
P7 (kontrol) & $13,20 \mathrm{ab}$ & $12,57 \mathrm{ab}$ & $3,83 \mathrm{a}$ & $67,0 \mathrm{a}$ & $12,60 \mathrm{a}$ & $4,8 \mathrm{a}$ & $1,25 \mathrm{a}$ \\
\hline
\end{tabular}

Keterangan: Angka-angka yang diikuti oleh huruf yang sama pada kolom yang sama tidak berbeda nyata pada uji Jarak Berganda Duncan taraf $5 \%$

\section{KESIMPULAN DAN SARAN \\ Kesimpulan}

Perlakuan terbaik terdapat pada karakter diameter dan tebal buah P2 (7 ml) dan P3 $(10 \mathrm{ml})$ yang menunjukkan respon berbeda nyata pada setiap perlakuan yang diamati. Dosis perlakukan tersebut dapat menjadi rekomendasi untuk digunakan dalam meningkatkan hasil produksi tomat cherry.

\section{Saran}

Perlu dilakukan percobaan lebih lanjut seperti aplikasi kandungan dan dosis dari jenis nutrisi yang berbedabeda dalam pengembangan tomat cherry lokal Subang untuk meningkatkan produktivitas buah.

\section{UCAPAN TERIMA KASIH}

Ucapan terima kasih kepada Direktorat Riset dan Pengabdian Masyarakat, Direktorat Jenderal Penguatan Riset dan Pengembangan Kementerian Riset, Teknologi, dan Pendidikan Tinggi yang memberikan bantuan dana penelitian melalui Program Hibah Penelitian Dosen Pemula (PDP) dengan nomor kontrak penelitian 0301/PL41/KP/2019.

\section{DAFTAR PUSTAKA}

Ainina AN, Aini N. 2018. Konsentrasi Nutrisi AB Mix Dan Media Tanam Terhadap Pertumbuhan Dan Hasil Tanaman Selada Merah (Lactuca sativa L. var. crispa) Dengan Sistem Hidroponik Substrat. Junrnal Produksi Tanam. 6(8):1684-1693.

Baker A v., Pilbeam DJ. 2015. Essential Elements: Macronutrients. In: Hand Book of Plant Nutrition Second Edition. CRC Press. p. 17-261.

Caicedo AL, Schaal BA. 2004. Population structure and phylogeography of Solanum pimpinellifolium inferred from a nuclear gene. Mol Ecol. 13:1871-1882. doi:10.1111/j.1365-294X.2004.02191.x.

Hapsari R, Indradewa D, Ambarwati E. 2017. Pengaruh Pengurangan Jumlah Cabang dan Jumlah Buah terhadap Pertumbuhan dan Hasil Tomat ( Solanum Lycopersicum L .) The Effect of Pruning and Thinning on the Growth and Yield of Tomato. Vegetalika. 6(3):37-49.

Magdalena L, Adiwirman, Zuhry E. 2014. Uji Pertumbuhan Dan Hasil Beberapa Genotipe Tanaman Tomat (Lycopersicum esculentum Mill) Di Dataran Rendah. Jom Faperta. 1(2).
Manalu G, Mariati, Rahmawati N. 2019. Pertumbuhan dan Produksi Tomat Cherry pada Konsentrasi Nutrisi yang Berbeda dengan Sistem Hidroponik: The Growth and Production of Cherry Tomato at Different Concentrations of Nutrient with Hydroponic System. J Online Agroekoteknologi. 7(1):117-124.

Maulana E, Idrus M. 2010. Pengaruh Interval Waktu Pemberian Air terhadap Produktivitas Tanaman Tomat di Lahan Kering Dataran Rendah pada Musim Kemarau. J Penelit Pertan Terap. 10(3):207-212.

Muhadiansyah TO, Setyono, Adimihardja SA. 2016. Efektivitas Pencampuran Pupuk Organik Cair Dalam Nutrisi Hidroponik Pada Pertumbuhan Dan Produksi Tanaman Selada ( Lactuca sativa L .). J Agronida. 2(April):37-46.

Murtic S, Oljaca R, Smajic Murtic M, Vranac A, Akagic A, Civic H. 2018. Cherry Tomato Productivity as Influenced By Liquid Organic Fertilizer Under Different Growth Conditions. J Cent Eur Agric. 19(3):503-516. doi:10.5513/JCEA01/19.3.2168.

Naibaho DC, Barus A, Irsal. 2012. Pengaruh Campuran Media Tumbuh dan Dosis Pupuk NPK (16:16:16) Terhadap Pertumbuhan Kakao (Theobroma cacao L.) Di Pembibitan. J Online Agroekoteknologi. 1(1):114.

Nasrulloh N, Mutiarawati T, Sutari W. 2016. Pengaruh Penambahan Arang Sekam Dan Jumlah Cabang Produksi Terhadap Pertumbuhan Tanaman, Hasil Dan Kualitas Buah Tomat Kultivar Doufu Hasil Sambung Batang Pada Inceptisol Jatinangor. J Kultiv. 15(1):26-36. doi:10.24198/kltv.v15i1.12010.

Nio Song A. 2012. Evolusi Fotosintesis pada Tumbuhan. J IIm Sains. 12(1):28. doi:10.35799/jis.12.1.2012.398.

Nugraha RU, Susila AD. 2015. Sumber Sebagai Hara Pengganti AB mix pada Budidaya Sayuran Daun Secara Hidroponik. J Hortik Indones. 6(1):11-19.

Oliveira LKB de, Costa RS da, Santos JLG dos, Lima FE de O, Amorim AV, Marinho AB, Mesquita RO. 2018. Growth and Physiology of Cherry Tomatoes Under Organic Fertilization in Different Environments. J Agric Sci. 10(10):349. doi:10.5539/jas.v10n10p349. 
Ramdani H, Rahayu A, Setiawan H. 2018. Peningkatan Produksi dan Kualitas Tomat Ceri (Solanum lycopersicum var. cerasiforme) dengan Penggunaan Berbagai Komposisi Media Tanam dan Dosis Pupuk SP-36 Increasing. J Agronida. 4(April):9-17.

Romalasari A, Sobari E. 2019. Produksi Selada (Lactuca sativa L.) Menggunakan Sistem Hidroponik Dengan Perbedaan Sumber Nutrisi. J Agriprima, J Appl Agric Sci. 3(1):41-50. doi:10.25047/agriprima.v3i1.158.

Sahera WO, Sabaruddin L, Safuan LO. 2012. Pertumbuan dan produksi tomat (Lycopersicum esculentuma Mill) pada berbagai dosis bokhasi kotoran sapi dan jarak tanam. J Berk Penelit Agron. 1(2):102-106.

Smith M. 1992. Irrigation Schelduling. In: CROPWAT, a computer program for irrigation planning and management. Rome: FAO. p. 35-47.

Sobari E. 2015. Budidaya Paprika Analisis Usaha pada Bangunan Screen House dengan Sistem Drip Irrigation. 1st ed. Yogyakarta: Graha IImu.

Sobari E, Piarna R. 2019. Pengaruh Perbedaan Dosis Nutrisi Terhadap Karakter Pertumbuhan Dan Hasil Tomat Cerry (Solanum pimpinellifolium) Lokal Subang Dengan Sistem Irigasi Tetes. Gontor AGROTECH Sci J. 2(5):1-13. doi: 10.21111/agrotech.v5i2.3443.
Sobari E, Piarna R, Aris MA. 2019. Respon Fase Vegetatif Tomat Cherry Lokal Cijambe Subang ( Solanum pimpinellifolium ) Terhadap Aplikasi Dosis Nutrisi Sistem Irigasi Tetes. In: 10th Industrial Research Workshop and National Seminar. Vol. 10. Politeknik Negeri Bandung. p. 258-263.

Venkadeswaran E, Vethamoni PI, Arumugam T, Manivannan N. 2018. Evaluating the yield and quality characters of cherry tomato [ Solanum lycopersicum ( $L$.) var . cerasiforme Mill .] genotypes. Chem Stud. 6(3):858-863.

Wasonowati C. 2016. Peningkatan Produksi dan Kualitas Tomat ( Lycopersicon esculentum ) dengan Sistem Budi daya Hidroponik. Rekayasa. 3(2):83-89.

Wijayanti E, Susila AD. 2013. Pertumbuhan dan Produksi Dua Varietas Tomat ( Lycopersicon esculentum Mill .) secara Hidroponik dengan beberapa Komposisi Media Tanam Growth and Production of Two Tomato ( Lycopersicon esculentum Mill .) Varieties Hidroponically with some Growing Media Co. Bul Agrohorti. 1(1):104-112.

Zebua MJ, Suharsi TK, Syukur M. 2019. Studi Karakter Fisik dan Fisiologi Buah dan Benih Tomat (Solanum lycopersicum L.) Tora IPB. Bul Agrohorti. 7(1):69. doi:10.29244/agrob.7.1.69-75. 